\title{
International Law as a Crisis Discourse
}

\author{
The Peril of Wordlessness
}

Jean d'Aspremont

On ne fait pas n'importe quoi avec la langue. ${ }^{1}$

International law lives off crises, lives its crises, and lives in crisis. International law is a discourse for crisis, about crisis, and in crisis. In short, international law is a crisis discourse. In that sense, engaging with international law from the vantage point of crisis hardly adds anything, let alone proves novel. International lawyers are the masters of a discourse that is all about containing, making, and surviving crises in an interventionist, ${ }^{2}$ and managerial spirit. ${ }^{3}$ Against this backdrop, the very extensive literature that burgeoned following the outbreak of the COVID-19 pandemic is nothing but business as usual for a crisis discourse like international law. ${ }^{4}$ And yet, as I will try to demonstrate

1 Jacques Derrida, Apprendre à vivre enfin (Galilée 2005) 38.

2 I have looked at the interventionist dimension of international legal discourses elsewhere. See Jean d'Aspremont, 'Cyber Operations and International Law: An Interventionist Legal Thought' (2016) 21 Journal of Conflict \& Security Law 575.

3 I have looked at the managerial dimension of international legal discourses elsewhere. See Jean d'Aspremont, 'Jenks' Ethic of Responsibility for the Disillusioned International Lawyer' (2020) $31 \mathrm{EJIL}$ (forthcoming).

4 International lawyers have been extensively discussing whether the pandemic constitutes a situation covered by existing obligations and their exceptions under international trade law or international investment law, whether the situation created by the pandemic constitutes a circumstance precluding wrongfulness under the law of State responsibility, whether obligations in terms of human rights law and refugee law are suspended by virtue of the pandemic, whether the pandemic gives rise to new primary obligations in terms of international human rights law or international humanitarian law, whether the pandemic gives rise to an obligation of due diligence or an obligation to cooperate, whether the pandemic gives rise to a threat to international peace and security under the international law of collective security, whether cyber operations by States that have consequences for the research, trial, manufacture and distribution of a vaccine are prohibited, whether domestic

(C) JEAN D'ASPREMONT, 2022 | DOI:10.1163/9789004472365_009

This is an open access chapter distributed under the terms of the CC BY-NC-ND 4ealicensepremont - 9789004472365 Downloaded from Brill.come4/26/2023 08:34:25AM 
in this short chapter, international law's revelling in crises may prove to be, within a few decades, the very cause of international law's self-debilitation, self-exhaustion, and self-depletion.

What international law does to the world, it does it with words. In fact, international law's interventions in crises and management thereof hinge on there being words to capture what international law purports to do and what international law is meant to apply to. Short of any adequate terminological apparatus, international law loses most of its interventionist and managerial edge. As this chapter seeks to demonstrate, it is because of this dependence on words that the omnipresence of crisis narratives in international legal thought and practice may prove most alarming. Indeed, if any phenomenon deemed to be out of normality comes to be elevated to, reduced to, or, simply made, a crisis, one may wonder what words international law can and should brandish in facing the seemingly most pressing and greatest cataclysm of recent human history, namely the looming climate catastrophe. ${ }^{5}$ It is argued here that, should international law let the looming climate catastrophe - as well as the calamitous consequences of the measures necessary to avert it - be absorbed in its crisis narratives and in what is called here its 'normally abnormal normality', international law would be condemned to wordlessness. This would be so despite having had the luxury of being able to foresee it.

This short chapter starts by sketching out the way in which international law comes to function as a crisis discourse, that is, a discourse for crisis, about crisis, and in crisis (1). It then elaborates on why crisis narratives are omnipresent in international legal thought and practice, showing that crises amount to a discursive necessity for international law (2). This chapter then develops its main argument according to which crisis-centred international law,

measures to contain the pandemic breach international human rights law, whether the pandemic and the behaviour of States in relation thereto can fall within the jurisdiction of international courts - to name only a few of the legal issues that drew attention in the recent literature. This literature on CoviD-19 and international law is, less than a year since the outbreak of the pandemic, already too abounding to be referenced comprehensively. See, however, the numerous blog entries on $<$ www.ejiltalk.org $>$. See also the legal scholarship referenced in the Oxford University Press COVID-19 content hub <https://academic.oup.com/ journals/pages/coronavirus >. See also the overview provided by Armin von Bogdandy and Pedro Villareal, 'International Law on Pandemic Response: A First Stocktaking in light of the Coronavirus Crisis' (2020) MPIL Research Paper 2020-07 < https://papers.ssrn.com/sol3/ papers.cfm?abstract_id=3561650 $>$ accessed 19 April 2021; See also the special symposium dedicated to 'The International Legal Order and the Global Pandemic' in (2020) 114(4) AJIL.

5 Whilst this chapter focuses on the climate catastrophe, other catastrophes are surely on the horizon and could also be mentioned like the collapse of biodiversity, a global nuclear fallout, the Kessler syndrome, etc. 
confronted with the upcoming greatest catastrophe of recent human history, is at risk of being wordless and of losing its world-making role in a matter of a few decades (3).

Two important caveats are warranted at this preliminary stage. First, the point developed in this chapter cannot be reduced to an arcane and detached literary exercise, let alone a nihilistic one. If anything, caring for the words of international law means caring for what international law can potentially be doing. Indeed, words matter because they constitute the first step of any intervention on the part of international law on the "outside". 6 It is through words that international law does what it does, and thus destroys, silences, and discriminates but also shapes, guides, and prompts action. In that sense, as far as international law is concerned, there is nothing more concrete than words. For that reason, wordlessness is no minor threat for international law. Second, it must be acknowledged that the argument made in this chapter may itself be articulated around a certain idea of crisis. After all, the idea of the peril of wordlessness could be construed as just another variant of the crisis narratives that populate international legal thought and practice. In that sense, the discussion provided in this chapter could be critically scrutinised in the very same way as it itself evaluates the way in which international law functions as a crisis discourse, let alone be charged for indulging in a performative contradiction. ${ }^{7}$ Yet, it is argued here that that the resort to the idea of the peril of wordlessness in this chapter - and thus to a possible crisis narrative - is no conceptual, methodological and theoretical obstacle to this chapter's inquiry in the functioning of international law as a crisis discourse. ${ }^{8}$

\section{A Discourse for Crisis, about Crisis, and in Crisis}

International law, as a crisis discourse, is a discourse based around crisis, for crisis, and in crisis. That is, it is a discourse that lives off crises, lives its crises,

6 See generally, Jean d'Aspremont, 'Wording in International Law' (2012) 25 LJIL 575.

7 This objection is an objection commonly made by Jürgen Habermas, The Philosophical Discourse of Modernity: Twelve Lectures (Frederik Lawrence tr, Polity Press 1987) 185-186, 279. See also Alasdair MacIntyre, Three Rival Versions of Moral Inquiry: Encyclopaedia, Genealogy, and Tradition (University of Notre Dame Press 1990) 55-56.

8 In the same vein, see Jean-François Lyotard, La Condition Postmoderne (Editions de Minuit 1979) 51; Theodor Adorno and Max Horkheimer, Dialectic of Enlightenment (Verso 1997) 7-9. See also the remarks of Susan Marks, 'False Contingency' (2009) 62 CLP 1, 1-21. 
and lives in crisis. This section sketches out three of the main features of what it means for international law to be a crisis discourse.

First, international law is a discourse for crises that lives off crises. It is the tool which is summoned whenever a phenomenon deemed to be outside normality is experienced. When international lawyers face a type of cruelty, indecency, poverty, complacency, or bankruptcy which they judge to be outside normality, they brandish an international legal rule or the formal powers of an international legal institution. ${ }^{9}$ Interestingly, international lawyers are not alone in invoking international law whenever a phenomenon is deemed to be outside normality. They are often assisted by policymakers, journalists, activists, one-line self-taught lawyers, etc. who commonly feel at ease raising international legal claims and who speak on behalf of international law to address the crises which they witness and experience. As a discourse for crisis, international law can be seen as a discursive tool that is on standby, charging in the garage, until it is fired up by international lawyers (and their associates) to tackle any new crisis appearing on their horizon..$^{10}$ From this perspective, international law is a discursive tool that supposedly accumulates knowledge through its repeated deployment and application to crises, and is a tool that is being constantly upgraded and enhanced. ${ }^{11}$ As a discourse for crises that lives off crises, international law is permanently profiled and vindicated as a tool that is fully adaptable according to an evolving and ever changing world. ${ }^{12}$

Second, international law is a discourse about crisis that lives its crises. It portrays the world as rhythmed by crises and revels therein. Crises are part of the world-making performances of international law..$^{13}$ When it is mobilized,

This has occasionally given rise to specific branches of international law entirely dedicated to crisis. On the idea of a disaster law, see Kristian Cedervall Lauta, Disaster Law (Routledge 2015); Rosemary Lyster, Climate Justice and Disaster Law (CUP 2015). On the idea of an international disaster response law see Andrea De Guttry, Marco Gestri, and Gabriella Venturini, International Disaster Response Law (TMC Asser Press 2012). On the idea of an international disaster relief law, see Stephen Green, International Disaster Relief: Toward a Responsive System (McGraw-Hill 1977).

10 On the idea of crisis as impetus for action, Joseph Powderly, 'International criminal justice in an age of perpetual crisis' (2O19) 32 LJIL 1, 3-6.

11 On the idea of crisis as a tool for the development of international law and for an opportunity to fill the gaps, Hilary Charlesworth, 'International Law: A Discipline of Crisis' (2002) 65 MLR 377,380 .

12 This is part of what I have called elsewhere the self-confirming modes of thinking on which international law is organized. See Jean d'Aspremont, 'A Worldly Law in a Legal World' in Andrea Bianchi and Moshe Hirsch (eds), International Law's Invisible Frames (oup 2021).

13 See generally, Monica Hakimi, 'The Work of International Law' (2017) $5^{8}$ Harv Int'l LJ 1. See Charlesworth (n 11) 382-383. 
international law contributes to the making of the crisis onto which it is projected as much as the crisis triggers the application of international law. ${ }^{14} \mathrm{~A}$ very elementary illustration thereof is non-compliance with an international legal obligation. ${ }^{15}$ Non-compliance is commonly understood as a crisis that triggers a need for international law's response and yet it is a crisis that is constituted by international law itself. That international law is a discourse about crisis is no minor thing. It should be recalled that like any idea projected onto the world, crises function as horses' blinders. For example, it is because migration is deemed a crisis rather than a normal expression of life or of human movement on earth, that it comes to call for an extraordinary response, limitations, containment, repression, etc. In that sense, international law's deployment of crisis narratives and thus the portrayal of a phenomenon as constituting a crisis is never neutral. Not only does international law elect certain crises and ignore others, ${ }^{16}$ but, more fundamentally, it reduces very complex phenomena to a limited set of extraordinary and pathological facts, thereby dramatically restricting how such phenomena are experienced, perceived, and approached. ${ }^{17}$ In short, as a discourse about crisis that lives its crises, international law defines normality and abnormality in the world, thereby carrying out some of its most dramatic world-making performances. ${ }^{18}$

Third, international law is a discourse in crisis. It constantly lives in crisis as it presents itself as being riven by interpretations or institutional practices that potentially undermine it, or as being inadequately equipped, or in need of reform. ${ }^{19}$ In doing so, international law constantly fuels a demand for reform and reformers, ${ }^{20}$ the latter being a role which international lawyers are commonly prompt to volunteer for. ${ }^{21}$ At the same time, being in a state of crisis

14 On self-confirming thinking in international law see d'Aspremont (n 12).

15 For a discussion of the common elevation of violations of international law into crises, see Charlesworth (n 11) 380.

16 ibid 384 .

17 See generally, Henri Bergson, La pensée et le mouvant (Flammarion 2014) 181.

18 See generally, Georges Canguilhem, Le normal et le pathologique (Presses Universitaires de France 2013). See also Michel Foucault, Histoire de la folie à l'âge classique (Gallimard 1976).

19 See Anne Orford, 'The Destiny of International Law' (2004) 17 LJIL 441; Charlesworth (n 11). On the extensive debates about the state of crisis of international criminal law, see Frédéric Mégret, 'The Anxieties of International Criminal Justice' (2016) 29 LJIL 197; Elies van Sliedregt, 'International Criminal Law: Over-Studied and Underachieving?' (2016) 29 LJIL 1; Powderly (n 10).

20 On the idea that crisis allows rewriting, see Alasdair McIntyre, Whose Justice? Which Rationality? (Duckworth 1988) 363 .

21 On the idea that crisis promotes a certain type of heroism within the discipline, see Charlesworth (n 11) 387 . 
serves a self-reproducing function for international law. ${ }^{22}$ Indeed, this selfdeclared state of crisis allows international law to constantly recognize its imperfection, while conveying a constant acknowledgement that it must be adjusted to the world and adapt its interventionist and managerial ambitions to what that world requires. In that sense, being a discourse in crisis, international law comes to look defective. And yet, such projection of its own limitations constitutes a cynical move on the part of international law, for this is what allows international law to affirm its full flexibility and thus its permanent state of renewal. ${ }^{23}$ As a discourse in crisis that lives in and with its own crisis, international law cynically makes itself vulnerable for the sake of affirming its invincible flexibility. ${ }^{24}$

\section{Crises as Discursive Necessities}

It is submitted in this section that living off crises, living one's crises, and being in crisis is not the result of a convention, a convulsion or an obsession but corresponds, more fundamentally, to three distinct discursive necessities of international law. ${ }^{25}$ This means that for any proposition under international law to be considered international law proper it must be seen as responding to the three crisis-related discursive necessities mentioned in this section. Short of responding to such crisis-related discursive necessities, any saying under international law would fall into discursive irrelevance and be demoted to a saying located outside international law. ${ }^{26}$ As the following paragraphs will

22 On the idea that modern discourses are always at the mercy of crisis and that this is something they do to themselves, see Peter Sloterdijk, Critique of Cynical Reason (University of Minnesota Press 1987) 7, 76 .

23 For a scholarly example of the elevation of crisis as a moment of self-reflection and selfexamination, see Francisco-José Quintana and Justina Uriburu, 'Modest International Law: Covid-19, International Legal Responses, and Depoliticization' (2020) 114 AJIL 687.

24 On this aspect of international law, see Jean d'Aspremont, 'International Legal Methods: Working for a Tragic and Cynical Routine' in Rossana Deplano and Nicholas Tsagourias (eds), Handbook on Research Methods in International Law (Elgar 2020). See more generally David Kennedy, 'When Renewal Repeats: Thinking Against the Box' (1999-2000) 32 NYU J Int'l L \& Pol 335.

25 On the idea that a field's anxieties are part of the fields' condition (with an emphasis on international criminal law), see Mégret (n 19).

26 It is important to highlight that the three crisis-related discursive necessities discussed in this section are not exclusive of other discursive necessities. For instance, international law is also informed by a constant sense (and staging) of imminent change. This is something which John Haskell and I have explored elsewhere. See John D. Haskell and 
show, each of the three crisis-related discursive necessities to which any saying under international law must respond takes the form of distinct ruptures by virtue of which international law justifies, affirms, and grounds itself. Living off crises, living one's crises, and being in crisis enable international law to articulate itself around specific ruptures which are necessary for international law to do what it does.

First, international law is nurtured by crises, for crises perpetuate the idea of there being ruptures from normality without which international law's interventions cannot be justified. As long as there are crises, there are projections of ruptures in the normality of the world, thereby creating the experience of a need for the restoration of normality. In that sense, crises secure the permanence of rupture from normality and thus of the need for normality-restoring interventions by international law. ${ }^{27}$ Said differently, crises enable a rupture from a state of normality where international law would have been neither justified nor relevant. ${ }^{28}$

Second, international law is informed by crisis narratives as international law is in a constant search for a rupture from the past, which allows it to affirm its uniqueness and relevance in the present. ${ }^{29}$ Indeed, each crisis which international law is called to tackle re-affirms, re-locates, and re-designates international law in the present. This means that each crisis is a new, and permanent, beginning for international law. ${ }^{30}$ In other words, crises enable a rupture from a past where international law would have been both static and anachronistic. ${ }^{31}$

Third, international law is riven by its own crisis which allows for a rupture from ontology, metaphysics, and contemplation. ${ }^{32}$ To be sure, the crisis which international law is permanently undergoing works as a reminder that international law was never a given inherited from metaphysics but is merely a

Jean d'Aspremont (eds), Tipping Points in International Law: Critique and Commitment (CUP 2021).

27 On the idea that crises legitimize action and create a sense of urgency, see Benjamin Authers and Hilary Charlesworth, 'The Crisis and the Quotidian in International Human Rights Law' (2014) 44 NYIL 19, 21, 25.

28 Terry Eagleton, The Function of Criticism (Verso 2005) 105: 'The fact that we are always in crisis secures deconstruction a safe, indeed, interminable future'.

29 Paul Ricoeur, La mémoire, l'histoire, l'oubli (Seuil 2000) 386-387.

30 According to Jürgen Habermas this is a central feature of modern discourses, also something which can be ascribed to Hegel. See Jürgen Habermas, The Philosophical Discourse of Modernity: Twelve Lectures (Frederik Lawrence tr, Polity Press 1987) 5-7.

31 On the extent to which crises and progress are intertwined, see Walter Benjamin, Sur le concept d'histoire (Olivier Mannoni tr, Payot 2013) ch 4, 65-66.

32 On the idea that modern discourses put an end to contemplative thinking, see Hannah Arendt, The Human Condition (2nd edn, University of Chicago Press 1998) 14-21. 
human creation, and one that has no other foundations than those that the discourse gives to itself. ${ }^{33}$ As a discourse in crisis, international law reminds its users that its conventional foundations are permanently re-discussed, redetermined, and re-affirmed, thereby making foundational contestation permanent. ${ }^{34}$ Crisis and foundational conventionality are two sides of the same coin. From this perspective, crises transcend international law from the ontological, essentialist and metaphysical validation ${ }^{35}$ of which international law would have not been able to find viable foundations. ${ }^{36}$

It must be acknowledged that the abovementioned distinct ruptures which are enabled by crisis narratives - and the discursive necessities to which they correspond - work in parallel but not together. In fact, the above sketch of the extent to which crises manifest three key discursive necessities should suffice to shed light on the possible contradictions between them and show that international law, as a crisis discourse, is certainly not a consistent discursive construction. ${ }^{37}$ For instance, it may be that the necessity of a rupture from the past contradicts the necessity of a rupture from ontology, metaphysics, and contemplation as the making of international law as a human creation necessarily historizes it and thus calls for its anchoring in the past. Likewise, the necessity of a rupture from normality may contradict the necessity of a rupture from ontology, contemplation, and metaphysics, for the conventionality to which the latter confines international law simultaneously condemns it to an indeterminate normality.

Actually, such contradictions between the three abovementioned crisisrelated discursive necessities do not matter as long as they are not disabling

33 Jacques Derrida, 'Force de Loi: Le 'Fondement Mystique de l'Autorité" (1990) 11 Cardozo L Rev 920, 942, 944; Michel Foucault, L'achéologie du savoir (Gallimard 1969) 87; Michel de Certeau, L'écriture de l'histoire (Gallimard 1975) 74; Habermas (n 30) 7.

34 According to Anne Orford, responses to crises include conventional attempts to find a new sovereign ground for the law, whether that be in the form of international organizations or of powerful national sovereigns who stand outside the law and guarantee its operation: Orford (n 19).

35 This is not exclusive of international law functioning in an ontological way. See Jean d'Aspremont, International Law as a Belief System (CUP 2017).

36 This does not mean that international law has ever succeeded in providing itself viable foundations. See Jean d'Aspremont, 'Three international lawyers in a hall of mirrors' (2019) 32 LJIL 367.

37 On the contradictions of modern discourses in general, see Paul Ricoeur, La mémoire, l'histoire, l'oubli (Seuil 200o) 399; Peter Sloterdijk, Critique of Cynical Reason (University of Minnesota 1987) 8, 11-12, 88-9o. On the idea that scrutinizing these contradictions is one of the goals of critique, see Roberto Mangabeira Unger, The Critical Legal Studies Movement. Another Time: A Greater Task (Verso 2015) 15. 
to the discourse - and I believe they are not as far as international law is concerned. More interesting, in my view, is the fact that crises are not only a state of the discourse - as discussed in section 1 - but also a necessary condition for it. Indeed, as has been indicated in this section, crises respond to a series of discursive necessities without which no proposition could be properly made under international law. This means that crises are an indispensable part of the normal state of international legal discourse. ${ }^{38}$ Crises are accordingly also a source of that discourse. And yet, at the same time, crises are defined by a presupposed normality set by international law (e.g. a stable climate, an absence of war, unimpeded trade, etc.). In that sense, crises are always both the source and the product of international legal discourse. ${ }^{39}$ Being generated by and generating the international legal discourse, crises materialize what is called here the normally abnormal normality of international law. As a crisis discourse, international law absorbs all the phenomena to which its application is envisaged into its own normally abnormal normality.

\section{3}

The Peril of Wordlessness in the Face of the Climate Catastrophe

As was indicated in the previous sections, international law is a crisis discourse whereby all the phenomena to which the application of international law is envisaged are absorbed into the latter's normally abnormal normality. This section reflects on the possible implications of international law's tackling the looming climate catastrophe as it tackles the pandemic crisis, the world institutions' crisis, the migration crisis, the cyber-security crisis, the financial markets' crisis, the sovereign debts' crisis, the terrorism crisis, etc. In particular, this section raises the question of what international law has to say about the looming climate catastrophe that threatens to ravage the world if it is apprehended through its own mundane crisis vocabulary? It is argued in this final section that, as long as international lawyers let the looming climate catastrophe be absorbed in the normally abnormal normality of international law and

38 On the idea that crisis becomes part of the order which international lawyers are responsible for, See Fleur Johns, Richard Joyce, and Sundhya Pahuja, 'Introduction' in Fleur Johns, Richard Joyce, and Sundhya Pahuja (eds), Events: The Force of International Law (Routledge 2011) $1-17$.

39 Compare with the argument of Benjamin Authers and Hilary Charlesworth according to which international human rights law is produced by crisis and dependent upon crisis. See Authers and Charlesworth (n 27). 
let it be captured as just a crisis, they expose international law to the peril of wordlessness as well as to the impossibility to perform any world-making role in relation to the climate catastrophe.

A very important caveat is warranted before this argument is developed further. The point here does not seek to imply that the pandemic crisis, the world institutions' crisis, the migration crisis, the cyber-security crisis, the financial markets' crisis, the sovereign debts' crisis, or the terrorism crisis are phenomena of second importance compared to the climate catastrophe. These "crises" of course matter as they relate to situations of very widespread and intolerable distress and suffering. One could claim that by absorbing these phenomena in the normally abnormal normality of international law, international lawyers already belittle the distress and the suffering caused by these crises. If this is the case, what is there to say about the consequences of absorbing the looming climate catastrophe in the normally abnormal normality of international law?

The claim made here, that the treatment of the looming climate catastrophe as a crisis and its absorption into international law's normally abnormal normality can lead to international law's wordlessness and its loss of any world-making role, will be substantiated in this section by responding to four counterarguments that can be anticipated in response thereto. The first counterargument pertains to the urgent nature of the abnormality and the impossibility of international law adjusting to it. In fact, in defence of international law (and of international lawyers), it could be contended that, as far as the pandemic crisis, the world institutions' crisis, the migration crisis, the cybersecurity crisis, the financial markets' crisis, the sovereign debts' crisis, the terrorism crisis, etc. are concerned, international law could only be mobilized "instantly", "without preparation" or "on the spot", leaving no other option than absorbing these phenomena in international law's existing normally abnormal normality. In other words, it could be said that the aforementioned crises erupted in a way that provided no time for equipping international law properly. This is the common we-have-no-time-for-a-rethink-but-mustact narrative. Whatever the weight of this argument, this is not a claim that can actually be entertained in relation to the looming climate catastrophe. Never has a catastrophe been anticipated and foreseen so long in advance as the looming climate catastrophe. Few would dispute the fact that this catastrophe is a long looming one, and one that leaves ample time for international law to reinvent its vocabularies as well as its narratives and to do away with its normally abnormal normality. This is not to say that there has been no effort to systematize international law's response to climate change, as is illustrated by the attempt to design an 'international law on climate 
change $^{40}$ or a 'climate disaster law'.41 Yet, these scholarly endeavours, however remarkable and lofty they may be, have remained short of a new vocabulary that raises to the level of what the looming climate catastrophe demands. Whatever the merits of the abovementioned scholarly enterprises, urgency can be no excuse for international law's complacency and by-default reliance on its usual crisis narratives.

The second counterargument that ought to be mentioned is that of the actual word-makers in international law. It could be argued that this whole debate about the wordlessness of international law vis-à-vis the looming climate catastrophe is not a scholarly matter for it lies in the hands of the actual international lawmakers who define the main legal categories through which international law intervenes in response to the problems of the world. This is the mundane Statesmake-international-law narrative often heard in - orthodox - scholarly circles. It is submitted here that scholars can hardly exculpate themselves by ascribing the possible wordlessness of international law vis-à-vis the looming climate catastrophe to the passivity of policy-makers, diplomats, legal advisers and all those who allegedly pull the strings behind the veil of the State. In other words, international legal scholars cannot seriously claim that they are themselves not the ones carving the words of international law and thus the terms of international law's action on climate change. Whilst the formal repositories of the discourse, i.e. the treaties, may well be made by States and all the policy-makers, diplomats, and legal advisers that come with them, the vocabulary of international law, and thus the words through which international law acts upon the "outside", are used, uttered, invoked, filled, interpreted, and substantiated by a wide range of actors, including scholars, who have the ability to (re)invent, (re)interpret, (re)calibrate, (re)organize, and (re)appropriate the words of international law. ${ }^{42}$

The third counterargument that can possibly be raised - and proved equally unconvincing - is that international law, as a crisis discourse, has inevitably learnt from the multiple situations of crises to which it has been applied over the last century. This counterargument bespeaks the old modern ideal ${ }^{43}$ of

40 See e.g. Benoit Mayer, The International Law on Climate Change (cup 2018). See also the references mentioned by Rosa Giles Carnero, 'Climate Change and International Law' in Tony Carty (ed), Oxford Bibliographies in International Law (OuP 2017).

41 Rosemary Lyster and Robert Verchick (eds), Research Handbook on Climate Disaster Law: Barriers and Opportunities (Edward Elgar Publishing 2018).

42 I have explored this elsewhere. See d'Aspremont, 'Wording in International Law' (n 6). See also Jean d'Aspremont, Epistemic Forces in International Law (Edward Elgar 2016).

43 See generally, Bruno Latour, La fabrique du droit. Une ethnographie du Conseil d'Etat (La Découverte 2004) 235; Jean-François Lyotard, La Condition Postmoderne (Editions de Minuit 1979) 52. On the idea that each crisis looks alike and that what is accumulated is 
accumulated knowledge which is so commonly espoused by international lawyers ${ }^{44}$ and corresponds to the international-law-improves-through-practice narrative which is so cherished in practice-centric circles. ${ }^{45}$ It is submitted here that this counterargument is not more persuasive than the we-have-notime-for-a-rethink and the States-make-international-law narratives. Given that each intervention of international law in the continuously renewed crises of the world are only the materialization of a normally abnormal normality, there is nothing to be learnt from the common functioning of international law. Crises, understood as a materialization of international law's normally abnormal normality, only confirm and perpetuate what international law has always been doing. In other words, crises, being defined by international law according to its setting of normality and being indispensable to international law's functioning as discourse, exclude the possibility that anything can be learnt from themselves. Crises cannot simultaneously constitute international law, be constituted by international law, and be the source of accumulated knowledge about what international law does with crises.

Last, but not least, it could also be counterargued that the climate catastrophe can yet be averted and that there is no need for a rethink of international law's vocabulary and narratives as long as the catastrophe can be warded off. This echoes the don't-verse-in-cheap-catastrophism narrative. It must be acknowledged here that the looming climate catastrophe remains looming and that hope for preventive action remains - which is why the latter must definitely and unambiguously be pursued. Yet, it is argued here that averting

an accumulation of resemblance, see Michel Foucault, Les mots et les choses (Gallimard 1966) 45 .

44 See e.g. Jean d'Aspremont, 'The League of Nations and the Power of "Experiment Narratives" in International Institutional Law' (2020) 22 International Community Law Review 275 .

45 On the concept of practice in international law and practice-centricism of international legal literature, see Andrea Bianchi, International Law Theories: An Inquiry into Different Ways of Thinking (oup 2016) 7. See also Jean d'Aspremont, 'Theory and History: Ordering Through Distinctions' in Jean d'Aspremont (ed), The History and Theory of International Law, volume I and volume II (Edward Elgar 2020). See also Isaiah Berlin, 'The Pursuit of the Ideal' in Henry Hardy (ed), The Crooked Timber of Humanity: Chapters in the History of Ideas (2nd edn, Princeton University Press 2013) 1-20, esp. 5: 'With the new methods discovered by natural science, order could be introduced in the social sphere as well uniformities could be observed, hypotheses formulated and tested by experiment; laws could be based on them, and then laws in specific regions of experience could be seen to be entailed by wider laws; and these in turn to be entailed by still wider laws, and so on upwards, until a great harmonious system connected by unbreakable logic links and capable of being formulated in precise - that is, mathematical - terms, could be established'. 
the climate catastrophe will itself bring its own calamity, for the shift from a carbon-dependent to a carbon-free economy, albeit the better alternative, will itself bear disastrous consequences. ${ }^{46}$ This means that the disastrous consequences of the measures necessary to prevent or mitigate it should themselves not be absorbed in the normally abnormal normality of international law either. The looming climate catastrophe, as much as the calamitous measures necessary to avert it, demands that international law rise to the level of action demanded by the climate catastrophe and not limit itself to the comfort zone of its mundane crisis narratives.

Whilst seeking to debunk some of the most anticipated counterarguments about the need for a reinvention of the vocabularies of international law to prevent international law's wordlessness and its loss of any world-making role in front of the looming climate catastrophe (and of the disastrous consequences of the measures necessary to prevent or mitigate it), the previous paragraphs have so far fallen short of elucidating what precisely the contours of such new vocabulary - and the range of narratives that enabled thereby can possibly be. Yet, at the risk of disappointing the possible readership of this chapter, it is important to stress that defining the vocabulary and the narratives that would allow international lawyers to evade the crisis narratives, and the normally abnormal normality of international law, ought not to be the aim of the discussion conducted here. First, the main goal of the foregoing has primarily been to make international lawyers more familiar with the techniques, conditions, and limitations of their action on the world. ${ }^{47}$ Second, and more fundamentally, spelling out a possible new vocabulary and set of narratives that could possibly allow the looming climate change crisis to be approached outside international law's current normally abnormal normality can simply not be the answer to the problem of international law's wordlessness and loss of world-making power. Indeed, the point made here is not that the current crisis narratives of international law should be mechanically replaced by - say - a new set of catastrophe narratives. Such mechanical terminological substitution or an increased dramatization and differentiation in international law's narratives would not bring about the much-desired departure from international law's normally abnormal normality. ${ }^{48}$ This would simply be a type of

46 See Editorial, 'Is it the end of the oil age? Power in the 21st century' The Economist (London, 19-25 September 2020) 18-21.

47 For a few remarks on the benefits of such exercise, see Henri Bergson, Le possible et le réél (Quadrige 2011) 5.

48 On differentiation being a central aspect of the working of modern discourses, see Michel de Certeau, L'écriture de l'histoire (Gallimard 1975) 59. 
normally abnormal normality replacing another. Nor is it the claim made here that inventing a vocabulary or a set of narratives that provides a truer or more "scientific" representation of the reality of the looming climate catastrophe is required. In fact, international lawyers have now been sufficiently exposed to critical theory to appreciate that the "state of things" and "the natural order" are always the result of a performance ${ }^{49}$ and that "reality" and "nature" constitutes terribly powerful regimes of truth. ${ }^{50}$ For that reason, the question of vocabulary that is raised here should not be construed as a quest for better empirics. ${ }^{51}$

If the point made here is not about mechanically replacing crisis narratives by catastrophe narratives or about inventing a better representation of reality, what is it then that this chapter calls for? It is argued at this ultimate stage of the discussion that rising to the level that the climate catastrophe demands requires not only that the climate catastrophe be acknowledged as the catastrophe of all (present) times but, above all, that it be subject to a perpetual re-determination, re-appropriation, and re-narrativization that upholds the gravity of the catastrophe concerned and preserves international law's capacity to respond to it. ${ }^{52}$ This means more concretely that, instead of immobilizing the climate catastrophe - and the disastrous consequences of the measures necessary to prevent or mitigate it - in a fixed vocabulary and uniform narratives ${ }^{53}$ international lawyers' engagements with the climate catastrophe should materialize in a vocabulary that can be constantly $r e-$ determined and re-appropriated ${ }^{54}$ and in new sets of narratives that enable a permanent re-eventalization ${ }^{55}$ of the looming climate catastrophe. The alternative to the immobilization of crises narratives with respect to the looming

49 Judith Butler, Gender Trouble: Feminism and the Subversion of Identity (2nd edn, Routledge 1990) 45; Michel Foucault, Les mots et les choses (n 43) 11; Steven Winter, A Clearing in the Forest. Law, Life and Mind (University of Chicago Press 2001) 105, 114.

50 On the notion of truth regime, see Michel Foucault, Naissance de la biopolitique. Cours au Collège de France (1978-1979) (Gallimard Seuil 2004) 22.

51 Compare with Bruno Latour, 'Why has Critique Run out of Steam? From Matters of Fact to Matters of Concern' (2004) 30 Critical Inquiry 225, 231: 'The question was never to get away from facts but closer to them, not fighting empiricism but, on the contrary, renewing empiricism'.

52 Comp. with George Steiner, Errata. An Examined Life (Weidenfeld and Nicholson 1997) 5.

53 On this being a common trait of modern thinking, see Henri Bergson, La pensée et le mouvant (Flammarion 2014) 192-194.

54 In the context of gender, compare with Butler (n 49) 42.

55 On this notion, see Michael Foucault, 'Question of method' in Graham Burchell, Colin Gordon and Peter Miller (eds), The Foucault Effect: Studies in Governmentality (University of Chicago Press 1991) 73, 76 . 
climate catastrophe and to the disastrous consequences of the measures necessary to prevent or mitigate it thus lies in the possibility of a permanent re-determination, re-appropriation, and re-eventalization of the looming climate catastrophe outside current crisis narratives. ${ }^{56}$ Only a permanent redetermination, re-appropriation, and re-eventalization of the looming climate catastrophe outside current crisis narratives can prevent international lawyers from letting the looming climate catastrophe be reduced to an event - as it currently is under international law's crisis narrative - that can be either denied or banalized. It is also the only thing that can prevent international law from being reduced to a single set of formalistic responses that can be anticipated and easily rebutted by climate change deniers, the post-truth delinquents, the institutional vandals, the self-declared and self-taught twitter experts, and all the cynical climate change profiteers. ${ }^{57}$

The time has come to conclude this short essay. It has been stressed a few times in this chapter that the question of the wordlessness of international law in front of the looming climate catastrophe cannot be demoted to a purely literary exercise as it raises central questions about international law's ability to perform a world-making role. It should be added that this whole debate is not only about the world-making role of international law but simultaneously touches on international law's destiny. Should international law fail to raise to the level of response demanded by the looming climate catastrophe and instead limit itself to absorbing the latter in its normally abnormal normality, the (his) story $^{58}$ of international law may well end with a tragedy. Indeed, if tragedy is understood as a story of an average person, institution, discourse incapable of rising to the level of what the moment asks for, the (his)story of international law and climate change may well be tragic. After finding itself wordless in front of a ravaging of the earth, international law would simply turn, in the postclimate-catastrophe world, into an obsolete irrelevant discourse recorded in an Encyclopaedia of defunct discourses, next to Middle Age palliative medicine and flat earth physics. And this is not where the tragedy would end. It may also be that, in the post-climate-catastrophe world, international law comes to be

$56 \quad$ Henri Bergson, La pensée et le mouvant (Flammarion 2014) 241.

57 For a discussion of some of the limitations of the current formal constraints on international lawyers' capacity for action with respect to climate change, see Maiko Meguro, 'Litigating climate change through international law: Obligations strategy and rights strategy' (2O2O) 33 LJIL 933.

$5^{8}$ On the limits of the distinction between story and history, see Hayden White, Tropics of Discourse: Essays in Cultural Criticism (John Hopkins University Press 1978) 121. See also Paul Ricoeur, Temps et récit, Volume 1, L'intrigue et le récit historique (Seuil 1983) 17 and Paul Ricoeur, Temps et récit, Volume 2, La configuration dans le récit de fiction (Seuil 1984) 292. 
portrayed as the discourse that facilitated the ravaging of the world under the complacent sight of the climate change deniers, the post-truth delinquents, the institutional vandals, the self-declared and self-taught twitter experts, and all the cynical climate change profiteers. ${ }^{59}$ As international law continues to live off crises, live its crises, and be in crisis, international lawyers should seriously rethink their vocabularies and narratives, not only to do something for the world with their words, but also to salvage the legacy of international law.

59 Compare with Pierre Schlag, Laying Down the Law (New York University Press 1996) 166: "Maybe what comes next is that we stop treating "law" as something to celebrate, expand, and worship. Maybe we learn to lay down the law'. 